\title{
Review \\ Exploring the Pharmacological Potential of Glycyrrhizic Acid: From Therapeutic Applications to Trends in Nanomedicine
}

\author{
Mônica Helena Monteiro do Nascimento ${ }^{1,2, *}$ and Daniele Ribeiro de Araújo ${ }^{1,2, *(D)}$ \\ 1 Human and Natural Sciences Center, ABC Federal University, Santo Andre 09210-580, SP, Brazil \\ 2 Drugs and Bioactives Delivery Systems Research Group-SISLIBIO, ABC Federal University, \\ Av. dos Estados, 5001, Bl. A, T3, Lab. 503-3, Bangú, Santo Andre 09210-580, SP, Brazil \\ * Correspondence: monikhelena@gmail.com (M.H.M.d.N.); daniele.araujo@ufabc.edu.br or \\ draraujo2008@gmail.com (D.R.d.A.)
}

Citation: Nascimento, M.H.M.d.; de Araújo, D.R. Exploring the Pharmacological Potential of Glycyrrhizic Acid: From Therapeutic Applications to Trends in Nanomedicine. Future Pharmacol. 2022, 2, 1-15. https://doi.org/ 10.3390 / futurepharmacol2010001 Academic Editor: Juei-Tang Cheng

Received: 17 November 2021 Accepted: 29 December 2021 Published: 4 January 2022

Publisher's Note: MDPI stays neutral with regard to jurisdictional claims in published maps and institutional affiliations.

Copyright: (C) 2022 by the authors. Licensee MDPI, Basel, Switzerland. This article is an open access article distributed under the terms and conditions of the Creative Commons Attribution (CC BY) license (https:// creativecommons.org/licenses/by/ $4.0 /)$.

\begin{abstract}
Glycyrrhizic acid (GA) is the main active component of the licorice root, which has been known in traditional medicine since the ancient times. It is a molecule composed of a hydrophilic part, two glucuronic acid molecules, and a hydrophobic part, glycyrrhetinic acid. GA, when subjected to acid hydrolysis, releases $18 \beta$ - and $18 \alpha$-glycyrrhetinic acids. Glycyrrhetinic acid is most responsible for the pharmacological activities of licorice. GA has been reported to have multiple therapeutic properties: anti-viral, anti-inflammatory, antitumor, antimicrobial and hepatoprotective. Different approaches have revealed similar anti-inflammatory mechanisms of action of GA, such as the inhibition of translocation of nuclear factor $-\kappa \mathrm{B}(\mathrm{NF}-\kappa \mathrm{B})$ and suppression of Tumour Necrosis Factor alpha $(\mathrm{TNF}-\alpha)$ and interleukins. In this sense, several in vitro and in vivo studies have described the use of GA in the prevention and treatment of several complications, especially microbial/viral infection, and as a novel chemo-preventive agent for liver injury. Recent studies postulated that GA nanoparticles (GANPs) can be a promising strategy for the treatment of Severe Acute Respiratory Syndrome CoronaVirus 2 (SARS-CoV-2) infections. This mini-review summarizes the pharmacological activities of GA and its beneficial effects against various health problems and provides perspectives on the development of versatile nanoplatforms to overcome some limiting physicochemical properties and for enhancing the therapeutic benefits of GA.
\end{abstract}

Keywords: glycyrrhizic acid; anti-inflammatory; antitumor; antimicrobial; hepatoprotective; nanomedicine

\section{Introduction}

Historical references on medicinal plants bring reports of their use in virtually all ancient civilizations. The first descriptions of using plants for therapeutic purposes were written in cuneiform symbols. These descriptions were from Mesopotamia and date back to 2600 BC, including oil of cedar (Cedrus sp.), licorice (Glycyrrhiza glabra), myrrh (Commiphora sp.), and poppy (Papaver somniferum). Other bioactive molecules from vegetables were used as alternative treatments for many diseases [1,2].

Glycyrrhizic acid ((3 $\beta, 20 \beta)$-20-carboxy-11-oxo-30-norlean-12-en-3-yl-2-o- $\beta$-17-glucopyranuronosyl- $\alpha$-D-glucopyranosideronic acid or glycyrrhizin) (GA), a pentacyclic triterpene saponin and a weak acid soluble in water with three $\mathrm{pKa}$ values (pKa1 = 2.7; pKa2 = 2.8; $\mathrm{pKa} 3=4.7)$, is the main active component from licorice root $[3,4]$. GA is an amphiphilic molecule; the hydrophilic region is represented by the glucuronic acid residues, and the hydrophobic portion is the glycyrrhetic acid residue. It has a molecular weight of 822.92 $\mathrm{g} / \mathrm{mol}$, and the molecular form is $\mathrm{C}_{42} \mathrm{H}_{62} \mathrm{O}_{16}$ (Figure 1a) [5]. There are two stereoisomers of GA, $18 \alpha$-glycyrrhetinic acid, and 18 $\beta$-glycyrrhetinic acid, with different bioactivities: $18 \alpha$-glycyrrhetinic acid selectively inhibits the f $11 \beta$-hydroxysteroid dehydrogenase 1 (11 $\beta$-HSD1) enzyme but not $11 \beta$-HSD2, whereas $18 \beta$-glycyrrhetinic acid inhibits both the $11 \beta$ HSD1 and 11 $\beta$-HSD2 enzymes (Figure 1b,c) [6]. 


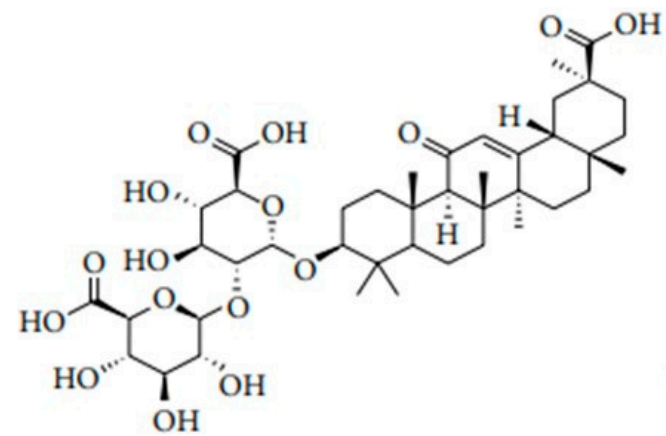

(a)

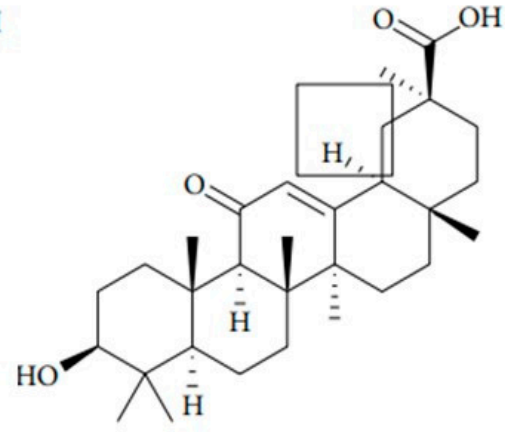

(b)

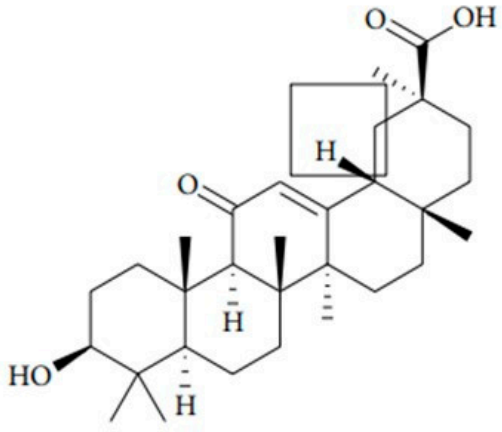

(c)

Figure 1. The structure of (a) glycyrrhizic acid (GA), (b) $18 \alpha$-glycyrrhetinic acid, and (c) $18 \beta-$ glycyrrhetinic acid.

GA has a long history of medicinal use. The first documents about the medicinal use of liquorice can be traced back to ancient Assyrian, Egyptian, Chinese, and Indian cultures [4]. The list of individual compounds isolated by now from various licorice herbs ( 13 botanical species of the world flora) includes more than 50 triterpenoids, above 200 individual phenolic compounds, dozens of polysaccharides and amino acids, and many others. The content of the glycyrrhizin compound of the triterpenoid series accounting for the characteristic sickly-sweet taste of the licorice root, representing (in the natural form) a mixture of potassium-calcium-magnesium salts of glycyrrhizic acid, varies within a $2-25 \%$ range. The content of phenolic compounds in the raw plant material generally amounts to 3-6 [4,7]. Among the other important biologically active substances and complexes, it is necessary to mention carbohydrates (simple sugars, pectins, and polysaccharides) amounting to $20 \%$, proteins, amino acids, and bases-up to $10 \%$, and lipids up to $3-4 \%$. GA is responsible for the sweet taste and comprises $6-14 \%$ of the dry root weight [7]. The three major GA-producing species are Glycyrrhiza glabra L., G. uralensis Fisch., and G. inflata Batal. Glycyrrhiza glabra is a perennial herb native to central and south-western Asia and the Mediterranean region. It is cultivated in the Mediterranean basin of Africa, in southern Europe, and in India [4].

GA is absorbed after enzymatic hydrolysis by commensal microbiota as glycyrrhetic acid [8]. In this way, the pharmacological effects of GA are essentially those obtained for glycyrrhetinic acid [9]. GA has been reported to have multiple therapeutic properties: anti-viral, anti-inflammatory, antitumor, anti-allergic, antimicrobial, antidiabetic, and hepatoprotective effects $[7,9,10]$. For these reasons, there is considerable interest in the extraction of GA with a water-soluble organic solvent by several methods reported in the literature, such as room temperature, ultrasonic extraction, and microwave-assisted extraction, and then its isolation through different methods, such as high-performance liquid chromatography (HPLC), resin column and adsorbent, supercritical fluid extraction, and with foam separation [5,11-13]. In this sense, this article summarizes the pharmacological activities of GA and its beneficial effects against various health problems (Figure 2), considering the molecular mechanism of the action of GA. Some evidence for GA efficacy was also addressed through the presentation of clinical trial results. Finally, challenges and perspectives on the development of versatile nanoplatforms to overcome some limiting physicochemical properties and for enhancing the therapeutic benefits of GA are highlighted. 


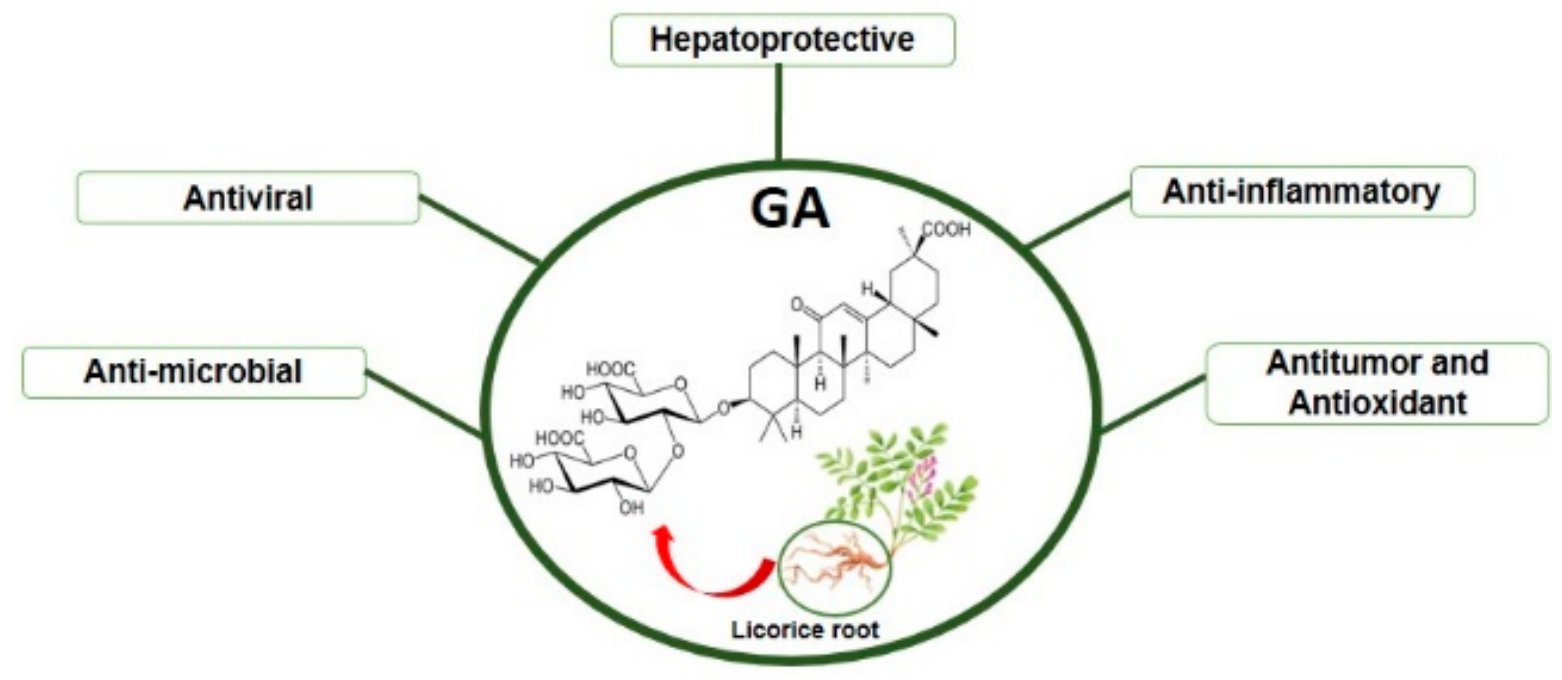

Figure 2. Principal pharmacological activities of GA.

\section{GA: Molecular Mechanisms of Action and Pharmacological Applications}

The pharmacological activities of GA include anti-inflammatory, antiviral, antitumor, anti-microbial, and hepatoprotective activity (Figure 2) (Table 1) [2,4,7,10]. This section will discuss the molecular mechanism and relevant publications based on the main therapeutic application of GA.

\subsection{Anti-Inflammatory and Hepatoprotective Activity}

Several clinical approaches reported that GA was efficient in the treatment of several inflammatory diseases in different organs, such as the liver, lung, kidney, intestine, and spinal cord. The anti-inflammatory activities of GA are based on the inhibition of synthesis, production, or activity of TNF- $\alpha$, interleukins IL-1 $\beta$ and IL-6, and also inhibited the activation of mitogen-activated protein kinase (MAPKs), including c-Jun N-terminal Kinase (JNK), p38 protein, and extracellular signal-regulated kinases (ERK) [2,14-17]. Even considering different pathologies, studies revealed similar anti-inflammatory mechanisms of action, such as the inhibition of translocation of nuclear factor- $\kappa \mathrm{B}$ (NF- $\kappa \mathrm{B}$ ) (Figure 3). For example, Xiao et al. (2010) found that GA induced anti-inflammatory effects through the NF- $\kappa$ B activation in immunopathogenesis in a mouse model of Propionibacterium acnes-induced acute inflammatory liver injury [18]. GA may provide a beneficial effect for treating vascular diseases associated with inflammation [19]. In this approach, it was demonstrated that GA interrupted both JNK/c-Jun and the inhibitor of nuclear factor kappa B (I $\kappa \mathrm{B} / \mathrm{NF}-\kappa \mathrm{B})$ signaling pathways, which decrease activator protein-1 (AP-1) and NF- $\kappa$ B mediated Intercellular Adhesion Molecule 1 (ICAM-1) expressions, leading to the suppression of monocyte adhesion to TNF- $\alpha$-activated endothelial cells. ICAM-1 plays a key role at the early stage of inflammatory response in facilitating leukocyte adhesion and transmigration in vascular endothelial cells [19]. In another study, Fu et al. (2014) investigated the anti-inflammatory effects of GA in Lipopolysaccharide (LPS)-stimulated macrophages. They determined that GA significantly inhibited LPS-induced NF- $\kappa$ B and interferon regulatory factor 3 (IRF3) activation and cytokine production through the inhibition of toll-like receptor 4 (TLR4) translocation and the disruption of lipid rafts [20]. Wang et al. (2017) also demonstrated that GA can be used as a potential agent for the treatment of endometriosis by inhibiting the expression and NF- $\kappa$ B activation induced by LPS [21]. The study demonstrated that GA inhibited LPS-induced Ciclooxigenase 2 (COX-2), TNF- $\alpha$, Interleukin-1 $\beta$ (IL-1 $\beta$ ), Nitric Oxide (NO), and Prostaglandin E2 (PGE2) expression in mouse endometrial epithelial cells (MEEC) [21]. Recently, GA was demonstrated to present potential therapeutic effects for osteoarthritis (OA) treatment. Jiang et al. (2020) showed that GA may inhibit IL-1 $\beta$-induced inflammation by blocking phosphatidylinositol 3-kinase $(\mathrm{PI} 3 \mathrm{~K}) /$ serine/threonine-protein kinases (Akt) phosphorylation and NF- $\kappa \mathrm{B}$ activation. GA 
also alleviated OA progression in surgically induced destabilization of the medial meniscus (DMM) mouse model [22].

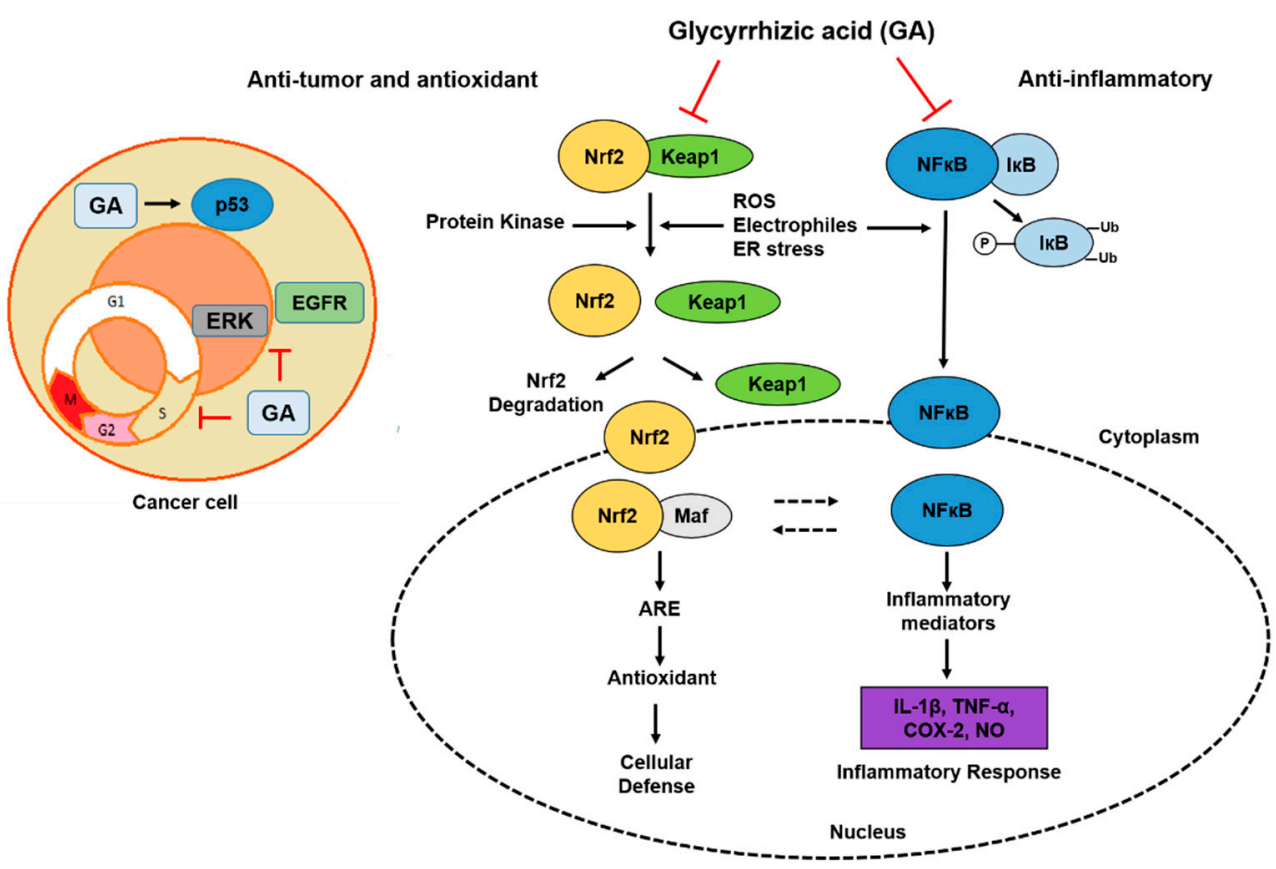

Figure 3. GA Anti-inflammatory and anti-cancer mechanisms of action. GA has an anti-inflammatory activity, acting through the NF- $\kappa$ B pathway. The regulation of NF- $\kappa$ B signaling by GA compresses the inhibition of phosphorylation and/or degradation of IkB; phosphorylation of IKK and nuclear translocation of NF- $\kappa$ B. The anti-tumor effects produced by GA are considered to occur via the Nrf2 pathway. The enhanced transcription of Nrf2 target genes causes a strong cytoprotective response, increasing resistance to carcinogenesis and other diseases that have oxidative stress involved in pathogenesis. GA also induces activation of tumor-suppressor p53 and inhibits phosphorylation of mitogen-activated protein kinase (MAPK), ERK, and epidermal growth factor receptor (EGFR), inhibiting cancer cell metastasis and proliferation, leading to apoptosis and anti-angiogenesis.

Several studies reported that GA was efficient in treating liver inflammation and also has an immune regulatory action (Table 1) $[2,14,18,23,24]$. According to the literature, the most important anti-inflammatory activity of GA on liver tissue is through the inhibition of TNF- $\alpha$ release and translocation of nuclear NF- $\kappa$ B [2]. Xiao et al. (2010) found that GA exhibits anti-inflammatory effects through the NF- $\kappa$ B activation in immunopathogenesis in a mouse model of Propionibacterium acnes-induced acute inflammatory liver injury [18]. The GA treatment inhibited liver granuloma formation and the production of inflammatory cytokines, such as Interferon gamma (IFN- $\gamma$ ) and TNF- $\alpha$, in MyD88-deficient mice [18]. Yoshida et al. (2007) demonstrated that GA mediated inflammatory response through the suppression of TNF- $\alpha$ by inhibition of LPS/D-galactosamine-induced liver injury [23]. GA has also attenuated chronic inflammatory diseases. The immune regulatory actions of GA were shown by suppressing the lytic pathway of the complement system [24]. GA also down-regulates the systemic inflammatory response syndrome (SIRS)-associated anti-inflammatory response manifestations through the inhibition of chemokine (C-C motif) ligand 2 (CCL2) production by polymorphonuclear neutrophils (PMN) in a mouse model [14]. This mechanism suggests that GA may prevent tissue injury in chronic hepatitis and other autoimmune and inflammatory diseases [24].

Many studies also indicate that the pharmacological actions of GA on liver tissue include anti-inflammatory, inhibition of hepatic apoptosis and necrosis, antiviral effects, and antitumor effects (Table 1) [2]. Matsumoto et al. (2013) evaluated the anti-HCV (Hepatitis C Virus) effects of GA and demonstrated that the treatment of HCV-infected Huh7 cells caused a reduction in infectious HCV. The suppression of viral release was from 
the inhibition effect of GA on the phospholipase A2 (PLA2) group [15]. GA has also been reported to have antioxidative properties in the human hepatoma cell line (HepG2) [25]. The GA hepatoprotective activity was due to its capacity to inhibit the metabolic activation of hepato-toxin (Aflatoxin B1-AFB1), a critical factor in the pathogenesis of chemical-induced carcinogenicity. Liang et al. (2015) showed that GA has inhibitory effects on hepatocyte apoptosis and liver fibrosis. The GA effects are associated with regulation of the expression levels of connective tissue growth factors, such as matrix metallopeptidase 2 and 9 (MMP2 and MMP9) proteins and collagen type I and III mRNA [26].

\subsection{Antiviral and Anti-Parasitic Activity}

Several studies have shown the antiviral activity of GA against different viruses, including Herpes simplex, Enterovirus, HIV, Influenza, and SARS-related coronaviruses [27-30]. GA can inhibit virus gene expression and replication, reducing the adhesion force, stress, and the high mobility group box 1 (HMGB1) binding to DNA. These antiviral mechanisms act to inhibit adsorption and penetration in the early steps of the virus' replicative cycle [4].

Early studies reported important results against the HIV virus. Hattori et al. (1989) presented preliminary evidence of the inhibitory effect of glycyrrhizin on immunodeficiency virus type 1 (HIV-1) replication in patients with immune deficiency syndrome (AIDS) [31]. These results were also verified by Mori et al. (1990) in hemophilia A patients with HIV infection. In this study, GA not only possessed an inhibitory effect on HIV replication, but also had interferon-inducing and natural killer (NK)-enhancing effects, which were essential for the first GA antiviral reports [27]. More recently, in an in vivo rat model of Herpes simplex virus (HSV) infection, GA suppressed the adhesion between cerebral capillary vessel endothelial cells (CCECs) and polymorphonuclear leukocytes (PMN) [28]. In a similar way, GA was also effective against other viral infections. Kuo et al. (2009) showed that GA protected host cells against Enterovirus type 71 (EV71) action. The water extract from G. uralensis showed a significant inhibition of EV71 attachment and penetration to the cells and the early steps of the viral replication cycle [29]. Other authors reported that G. uralensis ethanol extract produced an inhibitory effect on a chemoattractant (RANTES) released by influenza A virus (H1N1)-infected human bronchial epithelial cells (A549) [32]. In a recent approach, Cinatl et al. (2003) demonstrated that GA inhibits SARS-associated coronavirus (SARS-CoV-1) replication, adsorption, and penetration of the virus during the early steps of the replicative cycle in Vero cells [33]. Hoever et al. (2005) also showed that GA could inhibit the replication of coronavirus SARS in vitro [34]. In this way, based on antiviral activities of GA against several viruses, including SARS-CoV, some current authors are postulating that GA can be an optional strategy for the treatment of SARS-CoV2 infections alone and in combination with other drugs to combat the current COVID-19 pandemic [30,35-37].

GA also demonstrated anti-parasitic activity [38-40]. GA suppressed inflammation in Leishmania donovani infection by inhibiting COX-2-mediated prostaglandin E2 (PGE2) release in L. donovani-infected macrophages [38]. In an in vivo model, GA also decreased hepatic and splenic parasite burdens and inhibited the release of the cytokines IL-10 and TNF- $\alpha$ of infected BALB/c mice [39]. Similar to a previous work, Dinesh et al. (2017) investigated the potential of GA as an antileishmanial agent. This evaluation revealed that GA kills the parasite by affecting the sterol biosynthetic pathway, especially by inhibiting the L. donovani HMGR (3-hydroxy-3-methylglutaryl coenzyme A reductase) and altering ergosterol levels [41]. The in vitro anthelmintic activity of GA against gastrointestinal nematodes of small ruminants was investigated by Maestrini et al. (2021). In this study, GA was found to be highly active when used in the egg hatch test (EHT), larval development test (LDT), and larval migration inhibition test (LMIT) [40].

\subsection{Antibacterial Activity}

Most of the pharmacological actions of GA also include antimicrobial activity through the inhibition of bacterial infection by decreasing the expression of genes, inhibiting bacte- 
rial growth, and reducing the production of microbial toxins [42-45]. Several approaches have shown that GA has potent effects in inhibiting the activities of Gram-positive bacteria and Gram-negative bacteria [42-45]. Chung et al. (1998) reported, for the first time, the effect of GA on the inhibition of arylamine N-acetyltransferase (NAT) activities, substrates determined in Helicobacter pylori, and consequently, the GA inhibition of growth in the bacterium $H$. pylori [42]. Long et al. (2013) demonstrated in vitro and in vivo that GA inhibits methicillin-resistant Staphylococcus aureus (MRSA) growth by reducing the expression of key staphylococcal virulence factors, including hla and saeRS. These genes regulate the production of numerous virulence factors, including hemolysins, leukotoxins, and adhesins [44]. The alcoholic extract from the roots of G. glabra showed a significant antibacterial activity, developing areas of growth inhibition against Staphylococcus aureus, Escherichia coli, Pseudomonas fluorescens, and Bacillus cereus [45]. Yoshida et al. (2010) investigated the effects of GA on Pseudomonas aeruginosa. The results indicated that GA improved the production of antimicrobial peptides in tissues surrounding the burn area [43].

\subsection{Antitumor and Antioxidant Activities}

The main molecular antitumor mechanism of GA reported in the literature is through the down-regulation of proliferation, metastasis, cell-cycle arrest and apoptotic cell death, and transcription factor-nuclear factor kappa beta (NF- $\kappa \mathrm{B})$, as well as the inflammatory agents cyclooxygenase-2 (COX-2), prostaglandin E2 (PGE2), and nitric oxide (NO), while up-regulating p53 and p21/Cip1 to protect DNA from damage and promote DNA repair $[9,10,46-52]$ (Figure 3).

Several studies have reported the protective effects of GA against various cancer cell types, including oral, gastric, breast, skin, cervix, and liver [34,46,48-52]. Jiang et al. (2016) demonstrated the anticancer activities of GA against two human breast cancer cell lines (MCF-7 and MDA-MB-231) [47]. Studies in in vitro models showed significant GA-induced cytotoxicity against both cancer cell lines. Other cancer cells were also affected by GA treatment, such as gastric cancer cell lines (MKN28, AGS, SGC7901, and MKN45), where their growth cycle was arrested at the G2/M transition with consequent apoptosis [47]. Additionally, GA was able to delay and reduce UVB-radiation-induced skin cancer in a hairless mouse model of skin [46]. The molecular mechanism associated with the protective effects of GA involved the inhibition of NF-kB, COX-2, PGE2, and NO levels [46]. Those effects were also associated with the pronounced antioxidant activity of GA due to the presence of several isoflavonoids, including glabridine and its derivatives [53]. In this sense, several studies highlighted the in vitro and in vivo antioxidant activities of GA. These approaches demonstrated antioxidant activity against reactive oxygen species, such as hydroxyl radicals, peroxyl and superoxide ions, which play an important role in the treatment of diseases involving reactive oxygen species (ROS) or in mechanisms related to photoaging. GA may activate the nuclear factor (erythroid-derived-2)-like 2 (Nrf2) pathway through the redox regulation of Keap1, while it may impact cellular ROS levels through additional direct or indirect mechanisms $[2,4,7,10]$ (Figure 3). In the case of skin cancer, for UVB-radiation-induced tumor treatment, GA has been considered a natural antioxidant agent protecting mitochondrial functions in the presence of oxidative stress [54]. In other models, GA has demonstrated chemopreventive potential against DMH-induced colon carcinogenesis via suppressing the immunostaining of Ki-67, NF-kB

-p65, COX-2, iNOS, and VEGF while enhancing the immunostaining of p53, connexin43, caspase-9, and cleaved caspase-3 in the colon of Wistar rats [52]. In vivo studies demonstrate that GA induces programmed cell death, probably inhibiting the liver enzyme 11-hydroxysteroid dehydrogenase type I [55]. Lee et al. (2008) studied the toxic effect of GA in the human cervix and uterus tumor cell line SiHa. The results suggested that the GA action may be associated with the increased formation of ROS and the depletion of GSH by inducing changes in the mitochondrial membrane permeability, leading to cytochrome $\mathrm{c}$ release and caspase- 3 activation [48]. GA inhibits the proliferation of HepG2 cells in liver 
cancer, also increasing the formation of ROS, NO production, and loss of the mitochondrial membrane potential [50].

\subsection{Some Evidence for GA Efficacy: Clinical Trials}

As showed in the last sections, the anti-inflammatory, antiviral, antitumor, hepatoprtective and other pharmacological effects of GA has been demonstrated through in vitro and in vivo assays (Figures 2 and 3) (Table 1). In recent years, many new clinical uses of GA have been found, and their effects have also been studied in humans. This section summarizes various clinical implications of GA (Table 1).

GA plays a key role against radiation-induced skin damage by a mechanism believed to be associated with its anti-inflammatory activity [56]. The efficacy of two formulations containing about $20 \%$ GA were tested in a double-blind clinical trial for the treatment of atopic dermatitis; the higher concentration ( $2 \%$ ) was found to be more effective and reduced erythema, oedema, and itching scores [57]. In addition, a multicenter, randomized, placebocontrolled study in children found a hydrolipidic cream with GA, and demostrated safety and significant efficacy as nonsteroidal therapy in mild to moderate atopic dermatitis [58].

Clinical studies have focused on the pharmacological effects of GA on liver disorders.

Long-term use of GA in patients with chronic hepatitis $\mathrm{C}$ virus (HCV) was effective in preventing the development of hepatocellular carcinoma (HCC) [6]. Another study conducted in Japan showed that long-term GA injection therapy decreases the HCC rate in patients with IFN-resistant HCV-related chronic hepatitis and cirrhosis [59].

Some approaches have demonstrated the GA treating H. pylori infection increased the eradication rate in patients with peptic ulcer dyspepsia [60]. The biological mechanisms involve antibacterial and anti-adhesive effects against $H$. pylori by blocking the dihydrofolate reductase enzyme and inhibiting DNA gyrase [61].

GA is also a potent mucosal agent used effectively in the treatment of peptic ulcers. In a trial of carbenoxolone sodium in the treatment of gastric ulceration $[6,62]$, its therapeutic effects on peptic ulcers were found to be related to the pharmacological activity of carbenoxolone, a synthesized metabolite from GA [63]. The mechanism of action involves the increased local concentration of prostaglandins that promote mucous secretion and cell proliferation in the stomach [6,64].

These results summarize that the therapeutic effects of GA on liver, gastrointestinal, oral and skin disorders were found in a growing body of clinical trials, implying that GA could have various therapeutic properties.

Table 1. Glycyrrhizic acid pharmacological activities described in in vitro and in vivo models and through clinical trials.

\begin{tabular}{|c|c|c|}
\hline Pharmacological Activities & Main Results & References \\
\hline Anti-inflammatory & $\begin{array}{l}\text { GA exhibits antiinflammatory effects through inhibition of MIP-1 in } \\
\text { a mouse model of acute } P \text {. acnes-induced inflammatory liver injury. }\end{array}$ & [18] \\
\hline Anti-inflammatory & $\begin{array}{l}\text { GA interrupted JNK/c-Jun and I } \kappa \text { B } / N F-\kappa B \text { signaling pathways, } \\
\text { which decrease activator protein- } 1(\mathrm{AP}-1) \text { and NF- } \kappa \text { B mediated } \\
\text { ICAM- } 1 \text { expressions. }\end{array}$ & [19] \\
\hline Anti-inflammatory & $\begin{array}{l}\text { GA inhibits the expression of TNF- } \alpha, \text { IL-6, IL- } 1 \beta \text { and RANTES in } \\
\text { LPS-stimulated macrophages. }\end{array}$ & [20] \\
\hline Anti-inflammatory & $\begin{array}{l}\text { GA inhibits IL- } 1 \beta \text { induced inflammation by blocking PI3K/Akt } \\
\text { phosphorylation and NF- } \kappa \text { B activation and alleviated OA } \\
\text { progression in surgical-induced DMM mouse model. }\end{array}$ & [22] \\
\hline Anti-inflammatory & $\begin{array}{l}\text { GA inhibits the LPS/D-galactosamine-induced liver injury through } \\
\text { preventing inflammatory responses and IL-18 production. }\end{array}$ & [23] \\
\hline Anti-inflammatory & $\begin{array}{l}\text { GA may prevent tissue injury in chronic hepatitis and in many } \\
\text { autoimmune diseases by suppressing the lytic pathway of the } \\
\text { complement system. }\end{array}$ & [24] \\
\hline Anti-inflammatory & $\begin{array}{l}\text { GA was effective and reduced atopic dermatitis in a human and } \\
\text { children double-blind clinical trial. }\end{array}$ & [56-58] \\
\hline
\end{tabular}


Table 1. Cont.

\begin{tabular}{|c|c|c|}
\hline Pharmacological Activities & Main Results & References \\
\hline Anti-inflammatory & GA promoted ulcer healing in patiets with peptic ulcer. & {$[6,63,64]$} \\
\hline Antiviral & $\begin{array}{l}\text { GA augmented IFN-induced reduction of virus in the HCVcc } \\
\text { system (cell culture produced HCV). }\end{array}$ & [15] \\
\hline Antioxidant & $\begin{array}{l}\text { GA were able to increase the intracellular reduced glutathione } \\
\text { concentration, in AFB1-treated cells. }\end{array}$ & [25] \\
\hline Anti-apoptotic & $\begin{array}{l}\text { GA has inhibitory effects on hepatocyte apoptosis and liver fibrosis. } \\
\text { GA increased the number of OKT4 lymphocytes, and demonstrated }\end{array}$ & [26] \\
\hline Antiviral & $\begin{array}{l}\text { a suitable treatment for preventing the development of } \\
\text { asymptomatic carrier (AC) in hemophilia patients into AIDS. }\end{array}$ & [27] \\
\hline Antiviral & $\begin{array}{l}\text { GA attenuated inflammatory responses in HSV by inhibition of } \\
\text { adhesion between CCEC and PMN. } \\
\text { Water Extract of GA has inhibitory Inhibited Enterovirus } 71 \text { in a }\end{array}$ & [28] \\
\hline Antiviral & $\begin{array}{l}\text { Human } \\
\text { Foreskin Fibroblast Cell Line. }\end{array}$ & [29] \\
\hline Antiviral & $\begin{array}{l}\text { Inhibitory effect of GA on HIV replication in patients with AIDS. } \\
\text { GA has inhibitory effect on a chemoattractant (RANTES) released }\end{array}$ & [31] \\
\hline Antiviral & $\begin{array}{l}\text { by influenza A virus (H1N1)-infected human bronchial epithelial } \\
\text { cells. }\end{array}$ & [32] \\
\hline Antiviral & $\begin{array}{l}\text { GA inhibits replication, adsorption, and penetration of the virus } \\
\text { during the early steps of the replica-tive cycle in Vero cells. GA } \\
\text { inhibits replication of the SARS-associated virus. }\end{array}$ & [33] \\
\hline Antiviral & GA inhibits replication of the SARS-associated virus. & [34] \\
\hline Anti-parasitic & $\begin{array}{l}\text { GA suppressed inflammation in Leishmania donovani infection by } \\
\text { inhibiting COX-2-mediated PGE2 release. }\end{array}$ & [38] \\
\hline Anti-parasitic & $\begin{array}{l}\text { GA adecreased hepatic and splenic parasite burden and increased } \mathrm{T} \\
\text { cell proliferation in Leishmania-infected BALB/c mice. }\end{array}$ & [39] \\
\hline Anti-parasitic & $\begin{array}{l}\text { GA has anthelmintic activity against gastrointestinal nematodes of } \\
\text { small ruminants. }\end{array}$ & [40] \\
\hline Anti-parasitic & $\begin{array}{l}\text { GA has a potential antileishmanial chemotherapeutic agent by } \\
\text { killing the parasite affecting sterol biosynthetic pathway. }\end{array}$ & [41] \\
\hline Antibacterial & $\begin{array}{l}\text { GA inhibited Arylamine N-acetyltransferase (NAT) activities in a } \\
\text { strain of H. pylori. }\end{array}$ & [42] \\
\hline Antibacterial & $\begin{array}{l}\text { GA promoted antibacterial resistance of severely burned mice to } P \text {. } \\
\text { aeruginosa burn wound infection. }\end{array}$ & [43] \\
\hline Antibacterial & $\begin{array}{l}\text { GA reduced skin lesion size and attenuates expression of key } \\
\text { virulence genes in a mouse model of } S \text {. aureus. }\end{array}$ & [44] \\
\hline Antibacterial & $\begin{array}{l}\text { GA showed a significant antibacterial activity against } S \text {. aureus, E. } \\
\text { coli, P. fluorescens, and Bacillus cereus. }\end{array}$ & [45] \\
\hline Antibacterial & $\begin{array}{l}\text { GA increased the eradication rate of } H . \text { pylori in patients with } \\
\text { gastrointestinal disorders. }\end{array}$ & [60-62] \\
\hline Antioxidant & $\begin{array}{l}\text { GA were able to increase the intracellular reduced glutathione } \\
\text { concentration, in AFB1-treated cells. }\end{array}$ & [25] \\
\hline Anti-apoptotic & GA has inhibitory effects on hepatocyte apoptosis and liver fibrosis. & [26] \\
\hline Antitumor & $\begin{array}{l}\text { GA exhibited anti-tumor property in astric ancer cells partly by } \\
\text { inducing apoptosis and cell cycle arrest. }\end{array}$ & [47] \\
\hline Antitumor and Antioxidat & $\begin{array}{l}\text { GA induces apoptotic cell death in SiHa cells and exhibits a } \\
\text { synergistic effect against antibiotic, anti-cancer and drug toxicity. } \\
\text { GA has chemopreventive effect via modulation of inflammatory }\end{array}$ & [48] \\
\hline Antitumor & $\begin{array}{l}\text { markers and induction of apoptosis in human hepatoma cell line } \\
\text { (HepG2). }\end{array}$ & [50] \\
\hline Antibacterial & $\begin{array}{l}\text { GA suppresses the development of precancerous lesions via } \\
\text { regulating the hyperproliferation, inflammation, angiogenesis and } \\
\text { apoptosis in the colon of wistar rats. }\end{array}$ & [52] \\
\hline Antitumor and Antioxidat & $\begin{array}{l}\text { GA induced apoptosis and was found to modulate critical end } \\
\text { points of oxidative stress in c.ultured primary rat hepatocytes. }\end{array}$ & [54] \\
\hline Antitumor and Antioxidat & $\begin{array}{l}\text { GA induces programmed cell death, probably inhibiting the liver } \\
\text { enzyme 11-hydroxysteroid dehydrogenase type. }\end{array}$ & [55] \\
\hline Antitumor and Antiviral & $\begin{array}{l}\text { GA reduced the increased risk of hepatocellular carcinoma in } \\
\text { patients with HCC. }\end{array}$ & {$[6,59]$} \\
\hline
\end{tabular}




\subsection{Glycyrrhizic Acid and Their Therapeutic Associations-The Role of Nanomedicine}

As stated before, GA plays key roles in different pathophysiological processes. In this context, the delivery of GA in a controlled and targeted manner may result in new and effective treatments for hepatocarcinoma, viral, and inflammatory diseases [65-78]. This section discusses recent reports that describe the development of new nanomedicine strategies for GA delivery, as summarized in Table 2.

Table 2. Glycyrrhizic acid (GA)-loaded nanocarrier systems with their composition and main pharmacological effects.

\begin{tabular}{|c|c|c|c|}
\hline Nanomaterial & Composition & Main Results & References \\
\hline Nanoparticles & $\begin{array}{l}\text { Glycyrrhizic acid-based } \\
\text { nanoparticle suspension }\end{array}$ & $\begin{array}{l}\text { GA nanoparticle inhibited the activity of } \\
\text { LPS-induced inflammatory cytokine (NO, } \\
\text { PGE2, TNF- } \alpha \text {, and IL-6) production in } \\
\text { macrophage cells. }\end{array}$ & [71] \\
\hline Nanoparticles & $\begin{array}{l}\text { 10-hydroxycamptothecin } \\
\text { (HCPT)-loaded glycyrrhizic } \\
\text { acid-conjugated bovine serum } \\
\text { albumin nanoparticles }\end{array}$ & $\begin{array}{l}\text { GA-BSA-HCPT nanoparticles can target } \\
\text { liver tumor cells. }\end{array}$ & [72] \\
\hline Nanoparticles & $\begin{array}{l}\text { pDNA-polyethylenimine- } \\
\text { glycyrrhizic } \\
\text { acid }\end{array}$ & $\begin{array}{l}\text { pDNA/PEI/GL showed high gene } \\
\text { expressions in the liver, especially in } \\
\text { parenchymal cells after intravenous } \\
\text { administration. }\end{array}$ & [66] \\
\hline Nanoparticles & $\begin{array}{l}\text { Chitosan-katira gum } \\
\text { nanoparticles }\end{array}$ & $\begin{array}{l}\text { GA encapsulated in chitosan-katira gum } \\
\text { nanoparticles enhanced its } \\
\text { anti-inflammatory activity. }\end{array}$ & [75] \\
\hline Nanoparticles & $\begin{array}{l}\text { Hyaluronic acid-glycyrrhizic acid } \\
\text { succinate copolymers }\end{array}$ & $\begin{array}{l}\text { Enhanced liver-targeting, and all the } \\
\text { copolymers presented no significant } \\
\text { cytotoxicity to HepG } 2 \text { cells. }\end{array}$ & [21] \\
\hline Nanoparticles & $\begin{array}{l}\text { Glycyrrhizic acid-functionalized } \\
\text { graphene oxide }\end{array}$ & $\begin{array}{l}\text { GA-GO@DOX induced } \\
\text { mitochondria-mediated apoptosis } \\
\text { (MMA) of cancer cells. }\end{array}$ & [70] \\
\hline Nanoparticles & $\begin{array}{l}\text { Glycyrrhizic acid-loaded } \\
\text { pH-sensitive } \\
\text { poly-(lactic-co-glycolic acid) }\end{array}$ & $\begin{array}{l}\text { GA-loaded nanoparticles release GA to } \\
\text { the colon and treat bowel mucosal } \\
\text { inflammation. }\end{array}$ & [74] \\
\hline Nanoparticles & Glycyrrhizic acid & $\begin{array}{l}\text { GANPs had antiviral, anti-inflammatory, } \\
\text { and antioxidant effects in vitro and } \\
\text { in vivo. }\end{array}$ & [30] \\
\hline Micelles & $\begin{array}{l}\text { Paclitaxel-loaded glycyrrhizic } \\
\text { acid micelles }\end{array}$ & $\begin{array}{l}\text { PTX-loaded GA micelles demonstrated a } \\
\text { significant improvement in the } \\
\text { pharmacokinetic parameters of PTX after } \\
\text { oral administration. }\end{array}$ & [73] \\
\hline Micelles & $\begin{array}{l}\text { Podophyllotoxin-loaded } \\
\text { glycyrrhizic acid micelles }\end{array}$ & $\begin{array}{l}\text { The POD-loaded GA micelles caused less } \\
\text { skin inflammation than traditional POD } \\
\text { tincture. }\end{array}$ & [77] \\
\hline Liposomes & Pegylatedliposomes & $\begin{array}{l}\text { Nano-liposome encapsulation of silibinin } \\
\text { with glycyrrhizic acid increased the } \\
\text { biological activity of the free drugs. }\end{array}$ & [65] \\
\hline Micelles & $\begin{array}{l}\text { Glycyrrhizic acid-nafamostat } \\
\text { mesilate }\end{array}$ & $\begin{array}{l}\text { A computational method for screening } \\
\text { candidates for drug delivery systems } \\
\text { selected GA and nafamostat mesilate } \\
\text { (NM), which were converted into micelle } \\
\text { nanoparticles to improve drug stability } \\
\text { and to effectively treat COVID-19. }\end{array}$ & [78] \\
\hline Carbon dots & $\begin{array}{c}\text { Glycyrrhizic acid-based carbon } \\
\text { dots }\end{array}$ & $\begin{array}{l}\text { Biological experiments demonstrated } \\
\text { that Gly-CDs have excellent antiviral } \\
\text { activity against the porcine reproductive } \\
\text { and respiratory syndrome virus (PRRSV). }\end{array}$ & [76] \\
\hline
\end{tabular}


Recently, significant advances in nanoparticle-based liver-targeting delivery systems have been pointed out as strategies to treat hepatic cancer. Wang et al. (2017) synthesized hyaluronic acid-glycyrrhetinic acid succinate (HSG) nanoparticles with great targeting efficiency according to the GA graft ratio [21]. Similarly, the GA effect against the hepatocellular carcinoma (HCC) cell line (HepG2) was demonstrated by Ochi et al. (2016) [65]. They evaluated a co-encapsulated pegylated nano-liposome system based on two phyto anti-cancer drugs, GA and silibinin. In vitro cytotoxicity showed significantly greater coencapsulated nano-liposomes in the HepG2 cells compared to the fibroblasts. Kurosaki et al. (2014) developed a novel liver-targeted gene delivery vector by electrostatically coating the cationic complex of pDNA and polyethylenimine (PEI) with GA (pDNA/PEI/GL). The complex presented a stable negative particle size of about $100 \mathrm{~nm}$ and showed high gene expression comparable to that obtained for the complex with pDNA and PEI (pDNA/PEI) in human hepatoma cells (HepG2 pDNA/PEI/GL) without cytotoxicity. Additionally, the pDNA/PEI/GL nanoparticles showed high gene expression in the liver, and may be a promising liver-targeted gene vector [66].

GA is an amphiphilic molecule that can form host-guest complexes or micelle-type nanocarriers by self-assembly, thereby encapsulating the guest molecule and increasing its solubility [10]. GA may form dimers at low concentrations in the range of $0.01-1 \mathrm{mM}$ and micelles at high concentrations greater than $1 \mathrm{mM}$ [67]. This process has been studied and proved by various methods, such as NMR [10], small-angle scattering [68], and mass spectrometry [69]. As an interesting strategy, GA was applied to functionalize graphene oxide (GO) to deliver doxorubicina (DOX) for antitumor therapy [70]. The GA-GO@DOX showed low toxicity and highly improved mitochondria-mediated apoptosis (MMA) and anticancer efficacy compared to the non-GA-functionalized system. In fact, a previous study by $\mathrm{Zu}$ et al. (2013) reported a liver cancer-targeted drug delivery system by using 10-hydroxycamptothecin (HCPT) to produce 10-hydroxycamptothecinloaded 10lycyrrhizic acid-conjugated bovine serum albumin nanoparticles (GL-BSA-HCPT-NPs). The size of the NPs was about $157.5 \mathrm{~nm}$, and the zeta potential was $-22.51 \pm 0.78 \mathrm{mV}$, indicating adequate colloidal stability with high drug encapsulation efficiency and loading percentages (93.7\% and $10.9 \%$, respectively). The in vitro assays showed that GL-BSA-HCPT-NPs caused high inhibitory rates on cell proliferation of human hepatoma cells (SMMC7721). The cell uptake assay demonstrated that GA-conjugated NPs displayed a better performance rate of cell uptake than unconjugated NPs. GA was used as the carrier of paclitaxel (PTX), an antitumor drug against a wide range of tumors [72]. The PTX-loaded GA micelles prepared with an ultrasonic dispersion method displayed small particle sizes and spherical shapes, and the encapsulation efficiency was about 90\%. PTX-loaded GA micelles demonstrated a significant improvement in oral bioavailability in vivo, which could be largely due to the enhancement of the PTX absorption in the jejunum and colon intestine. These results suggested that GA-based micelles could be promising carriers for PTX oral delivery [73].

In addition to anticancer pharmacological effects, the GA anti-inflammatory efficacy has also been studied. Zeeshan et al. (2018) synthetized GA-loaded pH-sensitive poly(lactic-co-glycolic acid) nanoparticles (GA-loaded PLGA-NPs) to target and treat colonic mucosal inflammation. PLGA-NPs presented a particle size of approximately $200 \mathrm{~nm}$, a high encapsulation efficiency, and a desired surface chemistry that is pH-dependent. PLGA-NPs provided sustained GA release up to $72 \mathrm{~h}$ following the Gompertz kinetic mode and double protection against drug release at $\mathrm{pH} 1.2(<3 \%)$. Additionally, in vivo treatment alleviated the symptoms of inflammation in a dextran sodium sulfate (DSS)induced colitis mice model [74]. In a previous study, Wang et al. (2013) synthesized and evaluated the anti-inflammatory effects of GA-loaded nanoparticles prepared by a supercritical antisolvent process (SAS). In this process, the drug was first dissolved in the solvent, and then, the drug solution was quickly sprayed into supercritical fluids (the antisolvent). The SAS process allowed the control of the particle size within the nanometer range. GA nanoparticles presented a particle size of about $200 \mathrm{~nm}$ and an irregular shape and inhibited the inflammation mediators NO, PGE2, TNF- $\alpha$, and IL-6 [71]. 
In another approach, natural polymers were used as matrices for developing nanocarriers. For example, the polycationic chitosan and polyanionic gum katira were used for sustained GA, and its anti-inflammatory potential was evaluated in a carrageenan-induced rat paw edema method [75]. Chitosan-gum katira nanoparticles prepared by the ionic complexation method presented a spherical shape with a small size $(<100 \mathrm{~nm})$ and sustained the GA release up to $48 \mathrm{~h}$, evoking increased GA bioavailability through enhanced absorption, and hence improved the anti-inflammatory effect [75].

More recently, the antiviral properties of GA-conjugated carbon-dots (GA-CDs) were also studied [76]. The GA-CDs were synthesized by a hydrothermal method, and their antiviral mechanism was demonstrated by the inactivation of the porcine reproductive and respiratory syndrome virus (PRRSV) in vitro. The results showed that GA-CDs present antiviral activity with multisite inhibition mechanisms: inhibition of PRRSV invasion and replication, stimulation of cells to produce interferon, and inhibition of ROS production [76].

For other viral infections, Wang et al. (2016) evaluated GA micelles for transdermal delivery of podophyllotoxin (PT), a drug for the treatment of human papillomavirus type 6 and 11. This approach demonstrated that micelles containing PT presented a sustained drug release profile than that obtained for the PT solution [77]. Additionally, micelles attenuated the expression of inflammatory cytokines (TNF-a and IL-6) in skin tissue. Recent studies postulated that GA can be a promising strategy for the treatment of SARS-CoV-2 infections [30,35-37].

In this sense, GA nanoparticles (GANPs) were developed and presented pronounced inhibition of murine coronavirus MHV-A59 proliferation with reduced proinflammatory cytokine production caused by MHV-A59 or the N protein of SARS-CoV-2. In vivo investigations using the MHV-A59-induced surrogate mouse model of COVID-19 showed that GA nanoparticles specifically target areas with severe inflammation, such as the lungs, which appeared to improve the accumulation of GANPs and enhance the effectiveness of the treatment [30]. In this sense, a recent interesting approach described a novel computational method named carrier suitability scoring (CSS) for identifying drug carrier candidates using molecular functional groups [78]. After computational analyses, GA and nafamostat mesilate (NM) were selected and converted into micelle nanoparticles to improve drug stability and to effectively treat COVID-19. In vitro experiments were performed to confirm some parameters, such as the morphology of the spherical micelles with sizes from 300 to $400 \mathrm{~nm}$. Those systems also showed reduced cytotoxicity and potential biocompatibility.

\section{Final Considerations}

Glycyrrhizic acid is one of the most promising natural-derivative molecules due to its inherent pharmacological properties, such as antioxidant, anti-inflammatory, antimicrobial, and antitumoral. Additionally, the chemical structure of GA determines the formation of an amphiphilic molecule capable of self-association to form nanoparticle-like structures. In this sense, different nanotechnological approaches have been studied by using GA-based nanoparticles, micelles, liposomes, and carbon dots, for example, in an attempt to overcome the biopharmaceutical limitations of GA. Several studies reported an improvement in the pharmacological effects after GA encapsulation or incorporation into nanostructures. Most of them are devoted to the preparation and physicochemical characterization, showing important results regarding the enhancement of the pharmacological effects of GA, especially as anti-inflammatory, antiviral, and antitumoral nanomedicines. Although some nanotoxicological and immunological aspects deserve more detailed studies, the use of nanomedicines can be considered a potential new strategy for the future use and optimization of GA-based nanoformulations.

Funding: The authors are grateful for financial support provided by the Sao Paulo State Research Foundation (FAPESP, grant \#2019/20303-4) and National Council for Scientific and Technological Development (CNPq 307718/2019-0). This study was financed in part by the Coordenação de Aperfeiçoamento de Pessoal de Nível Superior_Brasil (CAPES)—Finance Code 001. 
Institutional Review Board Statement: Not applicable.

Informed Consent Statement: Not applicable.

Data Availability Statement: Not applicable.

Conflicts of Interest: The authors declare that they have no conflict of interest.

\section{References}

1. Tomazzoni, M.I.; Negrelle, R.R.B.; Centa, M.D.L. Fitoterapia Popular: A Busca Instrumental Enquanto Prática Terapêuta. Texto Context. -Enferm. 2006, 15, 115-121. [CrossRef]

2. Li, J.Y.; Cao, H.Y.; Liu, P.; Cheng, G.H.; Sun, M.Y. Glycyrrhizic Acid in the Treatment of Liver Diseases: Literature Review. Biomed Res. Int. 2014, 872139. [CrossRef] [PubMed]

3. Cirillo, G.; Curcio, M.; Parisi, O.I.; Puoci, F.; Iemma, F.; Spizzirri, U.G.; Restuccia, D.; Picci, N. Molecularly Imprinted Polymers for the Selective Extraction of Glycyrrhizic Acid from Liquorice Roots. Food Chem. 2011, 125, 1058-1063. [CrossRef]

4. Pastorino, G.; Cornara, L.; Soares, S.; Rodrigues, F.; Oliveira, M.B.P.P. Liquorice (Glycyrrhiza glabra): A Phytochemical and Pharmacological Review. Phyther. Res. 2018, 32, 2323-2339. [CrossRef] [PubMed]

5. Shen, S.; Chang, Z.; Liu, J.; Sun, X.; Hu, X.; Liu, H. Separation of Glycyrrhizic Acid and Liquiritin from Glycyrrhiza uralensis Fisch Extract by Three-Liquid-Phase Extraction Systems. Sep. Purif. Technol. 2007, 53, 216-223. [CrossRef]

6. Kwon, Y.J.; Son, D.H.; Chung, T.H.; Lee, Y.J. A Review of the Pharmacological Efficacy and Safety of Licorice Root from Corroborative Clinical Trial Findings. J. Med. Food 2020, 23, 12-20. [CrossRef]

7. Obolentseva, G.V.; Litvinenko, V.I.; Ammosov, A.S.; Popova, T.P.; Sampiev, A.M. Pharmacological and Therapeutic Properties of Licorice Preparations (A Review). Pharm. Chem. J. 1999, 33, 427-434. [CrossRef]

8. Ploeger, B.; Mensinga, T.; Sips, A.; Seinen, W.; Meulenbelt, J.; DeJongh, J. The Pharmacokinetics of Glycyrrhizic Acid Evaluated by Physiologically Based Pharmacokinetic Modeling. Drug Metab. Rev. 2001, 33, 125-147. [CrossRef]

9. Ming, L.J.; Yin, A.C.Y. Therapeutic Effects of Glycyrrhizic Acid. Nat. Prod. Commun. 2013, 8, 415-418. [CrossRef]

10. Selyutina, O.Y.; Polyakov, N.E. Glycyrrhizic acid as a multifunctional drug carrier-From physicochemicalproperties to biomedical applications: A modern insight on the ancient drug. Int. J. Pharm. 2019, 559, 271-279. [CrossRef]

11. Pan, X.; Liu, H.; Jia, G.; Shu, Y.Y. Microwave-Assisted Extraction of Glycyrrhizic Acid from Licorice Root. Biochem. Eng. J. 2000, 5, 173-177. [CrossRef]

12. Niu, G.G.; Xie, Y.C.; Lou, J.F.; Liu, H.Z. Isolation and Purification of Glycyrrhizic Acid with Solvent Extraction. Sep. Purif. Technol. 2005, 44, 189-196. [CrossRef]

13. Tian, M.; Yan, H.; Row, K.H. Extraction of Glycyrrhizic Acid and Glabridin from Licorice. Int. J. Mol. Sci. 2008, 9, 571-577. [CrossRef] [PubMed]

14. Takei, M.; Kobayashi, M.; Herndon, D.N.; Pollard, R.B.; Suzuki, F. Glycyrrhizin Inhibits the Manifestations of Anti-Inflammatory Responses That Appear in Association with Systemic Inflammatory Response Syndrome (SIRS)-like Reactions. Cytokine 2006, 35, 295-301. [CrossRef] [PubMed]

15. Matsumoto, Y.; Matsuura, T.; Aoyagi, H.; Matsuda, M.; Hmwe, S.S.; Date, T.; Watanabe, N.; Watashi, K.; Suzuki, R.; Ichinose, S.; et al. Antiviral Activity of Glycyrrhizin against Hepatitis C Virus in vitro. PLoS ONE 2013, 8, e68992. [CrossRef] [PubMed]

16. Yu, J.Y.; Ha, J.Y.; Kim, K.M.; Jung, Y.S.; Jung, J.C.; Oh, S. Anti-Inflammatory Activities of Licorice Extract and Its Active Compounds, Glycyrrhizic Acid, Liquiritin and Liquiritigenin, in BV2 Cells and Mice Liver. Molecules 2015, 20, 13041-13054. [CrossRef] [PubMed]

17. Yin, X.; Gong, X.; Zhang, L.; Jiang, R.; Kuang, G.; Wang, B.; Chen, X.; Wan, J. Glycyrrhetinic Acid Attenuates LipopolysaccharideInduced Fulminant Hepatic Failure in D-Galactosamine-Sensitized Mice by up-Regulating Expression of Interleukin-1 ReceptorAssociated Kinase-M. Toxicol. Appl. Pharmacol. 2017, 320, 8-16. [CrossRef] [PubMed]

18. Xiao, Y.; Xu, J.; Mao, C.; Jin, M.; Wu, Q.; Zou, J.; Gu, Q.; Zhang, Y.; Zhang, Y. 18ß-Glycyrrhetinic Acid Ameliorates Acute Propionibacterium Acnes-Induced Liver Injury through Inhibition of Macrophage Inflammatory Protein-1 $\alpha$. J. Biol. Chem. 2010, 285, 1128-1137. [CrossRef]

19. Chang, Y.L.; Chen, C.L.; Kuo, C.L.; Chen, B.C.; You, J.S. Glycyrrhetinic Acid Inhibits ICAM-1 Expression via Blocking JNK and NF-B Pathways in TNF- $\alpha$-Activated Endothelial Cells. Acta Pharmacol. Sin. 2010, 31, 546-553. [CrossRef]

20. Fu, Y.; Zhou, E.; Wei, Z.; Song, X.; Liu, Z.; Wang, T.; Wang, W.; Zhang, N.; Liu, G.; Yang, Z. Glycyrrhizin Inhibits Lipopolysaccharide-Induced Inflammatory Response by Reducing TLR4 Recruitment into Lipid Rafts in RAW264.7 Cells. Biochim. Biophys. Acta-Gen. Subj. 2014, 1840, 1755-1764. [CrossRef]

21. Wang, X.; Gu, X.; Wang, H.; Sun, Y.; Wu, H.; Mao, S. Synthesis, Characterization and Liver Targeting Evaluation of Self-Assembled Hyaluronic Acid Nanoparticles Functionalized with Glycyrrhetinic Acid. Eur. J. Pharm. Sci. 2017, 96, 255-262. [CrossRef]

22. Jiang, R.H.; Xu, J.J.; Zhu, D.C.; Li, J.F.; Zhang, C.X.; Lin, N.; Gao, W.Y. Glycyrrhizin Inhibits Osteoarthritis Development through Suppressing the PI3K/AKT/NF-KB Signaling Pathway: In Vivo and in Vitro. Food Funct. 2020, 11, 2126-2136. [CrossRef]

23. Yoshida, T.; Abe, K.; Ikeda, T.; Matsushita, T.; Wake, K.; Sato, T.; Sato, T.; Inoue, H. Inhibitory Effect of Glycyrrhizin on Lipopolysaccharide and D-Galactosamine-Induced Mouse Liver Injury. Eur. J. Pharmacol. 2007, 576, 136-142. [CrossRef] 
24. Fujisawa, Y.; Sakamoto, M.; Matsushita, M.; Fujita, T.; Nishioka, K. Glycyrrhizin Inhibits the Lytic Pathway of ComplementPossible Mechanism of Its Anti-Inflammatory Effect on Liver Cells in Viral Hepatitis. Microbiol. Immunol. 2000, 44, 799-804. [CrossRef]

25. Chan, H.T.; Chan, C.; Ho, J.W. Inhibition of Glycyrrhizic Acid on Aflatoxin B1-Induced Cytotoxicity in Hepatoma Cells. Toxicology 2003, 188, 211-217. [CrossRef]

26. Liang, B.; Guo, X.L.; Jin, J.; Ma, Y.C.; Feng, Z.Q. Glycyrrhizic Acid Inhibits Apoptosis and Fibrosis in Carbontetrachloride-Induced Rat Liver Injury. World J. Gastroenterol. 2015, 21, 5271-5280. [CrossRef] [PubMed]

27. Mori, K.; Sakai, H.; Suzuki, S.; Akutsu, Y.; Ishikawa, M.; Imaizumi, M.; Tada, K.; Aihara, M.; Sawada, Y.; Yokoyama, M.; et al. Effects of Glycyrrhizin (SNMC: Stronger Neo-Minophagen $\mathrm{G}^{\circledR}$ ) in Hemophilia Patients with HIV-1 Infection. Tohoku J. Exp. Med. 1990, 162, 183-193. [CrossRef] [PubMed]

28. Huang, W.; Chen, X.; Li, Q.; Li, P.; Zhao, G.; Xu, M.; Xie, P. Inhibition of Intercellular Adhesion in Herpex Simplex Virus Infection by Glycyrrhizin. Cell Biochem. Biophys. 2012, 62, 137-140. [CrossRef]

29. Kuo, K.K.; Chang, J.S.; Wang, K.C.; Chiang, L.C. Water Extract of Glycyrrhiza Uralensis Inhibited Enterovirus 71 in a Human Foreskin Fibroblast Cell Line. Am. J. Chin. Med. 2009, 37, 383-394. [CrossRef] [PubMed]

30. Zhao, Z.; Xiao, Y.; Xu, L.; Liu, Y.; Jiang, G.; Wang, W.; Li, B.; Zhu, T.; Tan, Q.; Tang, L.; et al. Glycyrrhizic Acid Nanoparticles as Antiviral and Anti-Inflammatory Agents for COVID-19 Treatment. ACS Appl. Mater. Interfaces 2021, 13, 20995-21006. [CrossRef] [PubMed]

31. Hattori, T.; Ikematsu, S.; Koito, A.; Matsushita, S.; Maeda, Y.; Hada, M.; Fujimaki, M.; Takatsuki, K. Preliminary Evidence for Inhibitory Effect of Glycyrrhizin on HIV Replication in Patients with AIDS. Antivir. Res. 1989, 11, 255-261. [CrossRef]

32. Ko, H.C.; Wei, B.L.; Chiou, W.F. The Effect of Medicinal Plants Used in Chinese Folk Medicine on RANTES Secretion by Virus-Infected Human Epithelial Cells. J. Ethnopharmacol. 2006, 107, 205-210. [CrossRef]

33. Cinatl, J.; Morgenstern, B.; Bauer, G.; Chandra, P.; Rabenau, H.; Doerr, H.W. Glycyrrhizin, an Active Component of Liquorice Roots, and Replication of SARS-Associated Coronavirus. Lancet 2003, 361, 2045-2046. [CrossRef]

34. Hoever, G.; Baltina, L.; Michaelis, M.; Kondratenko, R.; Baltina, L.; Tolstikov, G.A.; Doerr, H.W.; Cinatl, J. Antiviral Activity of Glycyrrhizic Acid Derivatives against SARS-Coronavirus. J. Med. Chem. 2005, 48, 1256-1259. [CrossRef] [PubMed]

35. Bailly, C.; Vergoten, G. Glycyrrhizin: An alternative drug for the treatment of COVID-19 infection and the associated respiratory syndrome? Pharmacol. Ther. 2020, 214, 107618. [CrossRef]

36. Chen, Y.; Liu, Q.; Guo, D. Emerging Coronaviruses: Genome Structure, Replication, and Pathogenesis. J. Med. Virol. 2020, 92, 418-423. [CrossRef] [PubMed]

37. Tian, X.; Gan, W.; Nie, Y.; Ying, R.; Tan, Y.; Chen, J.; Chen, M.; Zhang, C. Clinical Efficacy and Security of Glycyrrhizic Acid Preparation in the Treatment of Anti-SARS-CoV-2 Drug-Induced Liver Injury: A Protocol of Systematic Review and Meta-Analysis. BMJ Open 2021, 11, 1-6. [CrossRef]

38. Ukil, A.; Kar, S.; Srivastav, S.; Ghosh, K.; Das, P.K. Curative Effect of $18 \beta$-Glycyrrhetinic Acid in Experimental Visceral Leishmaniasis Depends on Phosphatase-Dependent Modulation of Cellular MAP Kinases. PLoS ONE 2011, 6, e29062. [CrossRef] [PubMed]

39. Bhattacharjee, S.; Bhattacharjee, A.; Majumder, S.; Majumdar, S.B.; Majumdar, S. Glycyrrhizic Acid Suppresses Cox-2-Mediated Anti-Inflammatory Responses during Leishmania Donovani Infection. J. Antimicrob. Chemother. 2012, 67, 1905-1914. [CrossRef] [PubMed]

40. Maestrini, M.; Molento, M.B.; Forzan, M.; Perrucci, S. In Vitro Anthelmintic Activity of an Aqueous Extract of Glycyrrhiza glabra and of Glycyrrhetinic Acid against Gastrointestinal Nematodes of Small Ruminants. Parasite 2021, 28, 64. [CrossRef]

41. Dinesh, N.; Neelagiri, S.; Kumar, V.; Singh, S. Glycyrrhizic Acid Attenuates Growth of Leishmania Donovani by Depleting Ergosterol Levels Neeradi. Exp. Parasitol. 2017, 176, 21-29. [CrossRef]

42. Chung, J.G.; Wu, L.T.; Chang, S.H.; Lo, H.H.; Hsieh, S.E.; Li, Y.C.; Hung, C.F. Inhibitory Actions of Berberine on Growth and Arylamine N- Acetyltransferase Activity in Strains of Helicobacter pylori from Peptic Ulcer Patients. Int. J. Toxicol. 1998, 18, 35-40. [CrossRef]

43. Yoshida, T.; Yoshida, S.; Kobayashi, M.; Herndon, D.N.; Suzuki, F. Pivotal Advance: Glycyrrhizin Restores the Impaired Production of $\beta$-Defensins in Tissues Surrounding the Burn Area and Improves the Resistance of Burn Mice to Pseudomonas Aeruginosa Wound Infection. J. Leukoc. Biol. 2010, 87, 35-41. [CrossRef]

44. Long, D.R.; Mead, J.; Hendricks, J.M.; Hardy, M.E.; Voyich, J.M. 18ß-Glycyrrhetinic Acid Inhibits Methicillin-Resistant Staphylococcus aureus Survival and Attenuates Virulence Gene Expression. Antimicrob. Agents Chemother. 2013, 57, 241-247. [CrossRef]

45. Rodino, S.; Butu, A.; Butu, M.; Cornea, P.C. Comparative Studies on Antibacterial Activity of Licorice, Elderberry and Dandelion. Dig. J. Nanomater. Biostructures 2015, 10, 947-955.

46. Cherng, J.M.; Tsai, K.D.; Yu, Y.W.; Lin, J.C. Molecular Mechanisms Underlying Chemopreventive Activities of Glycyrrhizic Acid against UVB-Radiation-Induced Carcinogenesis in SKH-1 Hairless Mouse Epidermis. Radiat. Res. 2011, 176, 177-186. [CrossRef] [PubMed]

47. Wang, H.; Ge, X.; Qu, H.; Wang, N.; Zhou, J.; Xu, W.; Xie, J.; Zhou, Y.; Shi, L.; Qin, Z.; et al. Glycyrrhizic Acid Inhibits Proliferation of Gastric Cancer Cells by Inducing Cell Cycle Arrest and Apoptosis. Cancer Manag. Res. 2020, 12, 2853-2861. [CrossRef] [PubMed] 
48. Lee, C.S.; Kim, Y.J.; Lee, M.S.; Han, E.S.; Lee, S.J. 18ß-Glycyrrhetinic Acid Induces Apoptotic Cell Death in SiHa Cells and Exhibits a Synergistic Effect against Antibiotic Anti-Cancer Drug Toxicity. Life Sci. 2008, 83, 481-489. [CrossRef] [PubMed]

49. Xiao, X.Y.; Hao, M.; Yang, X.Y.; Ba, Q.; Li, M.; Ni, S.J.; Wang, L.S.; Du, X. Licochalcone A Inhibits Growth of Gastric Cancer Cells by Arresting Cell Cycle Progression and Inducing Apoptosis. Cancer Lett. 2011, 302, 69-75. [CrossRef] [PubMed]

50. Hasan, S.K.; Siddiqi, A.; Nafees, S.; Ali, N.; Rashid, S.; Ali, R.; Shahid, A.; Sultana, S. Chemopreventive Effect of $18 \beta$-Glycyrrhetinic Acid via Modulation of Inflammatory Markers and Induction of Apoptosis in Human Hepatoma Cell Line (HepG2). Mol. Cell. Biochem. 2016, 416, 169-177. [CrossRef] [PubMed]

51. Hasan, M.K.; Ara, I.; Mondal, M.S.A.; Kabir, Y. Phytochemistry, Pharmacological Activity, and Potential Health Benefits of Glycyrrhiza Glabra. Heliyon 2021, 7, e07240. [CrossRef] [PubMed]

52. Khan, R.; Khan, A.Q.; Lateef, A.; Rehman, M.U.; Tahir, M.; Ali, F.; Hamiza, O.O.; Sultana, S. Glycyrrhizic Acid Suppresses the Development of Precancerous Lesions via Regulating the Hyperproliferation, Inflammation, Angiogenesis and Apoptosis in the Colon of Wistar Rats. PLoS ONE 2013, 8, 1-22. [CrossRef] [PubMed]

53. Konovalova, G.G.; Tikhaze, A.K.; Lankin, V.Z. Antioxidant Activity of Parapharmaceutics Containing Natural Inhibitors of Free Radical Processes. Bull. Exp. Biol. Med. 2000, 130, 658-660. [CrossRef] [PubMed]

54. Tripathi, M.; Singh, B.K.; Kakkar, P. Glycyrrhizic Acid Modulates T-BHP Induced Apoptosis in Primary Rat Hepatocytes. Food Chem. Toxicol. 2009, 47, 339-347. [CrossRef] [PubMed]

55. Horigome, H.; Homma, M.; Hirano, T.; Oka, K. Glycyrrhetinic Acid Induced Apoptosis in Murine Splenocytes. Biol. Pharm. Bull. 2001, 24, 54-58. [CrossRef]

56. Kalinowska-Lis, A.K. 18 b-Glycyrrhetinic Acid: Its Core Biological Properties and Dermatological Applications. Int. J. Cosmet. Sci. 2019, 41, 325-331. [CrossRef]

57. Saeedi, M.; Semnani, K.; Ghoreishi, M. The Treatment of Atopic Dermatitis with Licorice Gel. J. Dermatolog. Treat. 2003, 14, 153-157. [CrossRef]

58. Boguniewicz, M.; Zeichner, J.A.; Eichenfield, L.F.; Hebert, A.A.; Jarratt, M.; Lucky, A.W.; Paller, A.S. MAS063DP Is Effective Monotherapy for Mild to Moderate Atopic Dermatitis in Infants and Children: A Multicenter, Randomized, Vehicle-Controlled Study. J. Pediatr. 2008, 152, 854-859. [CrossRef]

59. Ikeda, K.; Arase, Y.; Kobayashi, M.; Saitoh, S.; Someya, T.; Hosaka, T.; Sezaki, H.; Akuta, N.; Suzuki, Y.; Suzuki, F.; et al. A Long-Term Glycyrrhizin Injection Therapy Reduces Hepatocellular Carcinogenesis Rate in Patients with Interferon-Resistant Active Chronic Hepatitis C: A Cohort Study of 1249 Patients. Dig. Dis. Sci. 2006, 51, 603-609. [CrossRef]

60. Hajiaghamohammadi, A.A.; Zargar, A.; Oveisi, S.; Samimi, R.; Reisian, S. To Evaluate of the Effect of Adding Licorice to the Standard Treatment Regimen of Helicobacter Pylori. Braz. J. Infect. Dis. 2016, 20, 534-538. [CrossRef]

61. Wittschier, N.; Faller, G.; Hensel, A. Aqueous Extracts and Polysaccharides from Liquorice Roots (Glycyrrhiza glabra L.) Inhibit Adhesion of Helicobacter Pylori to Human Gastric Mucosa. J. Ethnopharmacol. 2009, 125, 218-223. [CrossRef]

62. An, B.; Moon, B.S.; Kim, H.; Lim, H.C.; Lee, Y.C.; Lee, G.; Kim, S.-H.; Park, M.; Kim, J.B. Antibiotic Resistance in Helicobacter Pylori Strains and Its Effect on H. Pylori Eradication Rates in a Single Center in Korea. Ann. Lab. Med. 2013, 33, 415-419. [CrossRef]

63. Turpie, A.G.G.; Thomson, T.J. Carbenoxolone Sodium in the Treatment of Gastric Ulcer with Special Reference to Side-Effects Gut 1965, 5, 591-594. [CrossRef]

64. Pinder, R.M.; Brogden, R.N.; Sawyer, P.R.; Speight, T.M.; Spencer, R.; Avery, G.S. Evaluations on New Drugs. Drugs 1976, 11, 245-307. [CrossRef]

65. Ochi, M.M.; Amoabediny, G.; Rezayat, S.M.; Akbarzadeh, A.; Ebrahimi, B. In Vitro Co-Delivery Evaluation of Novel Pegylated Nano-Liposomal Herbal Drugs of Silibinin and Glycyrrhizic Acid (Nano-Phytosome) to Hepatocellular Carcinoma Cells. Cell J. 2016, 18, 135-148. [CrossRef]

66. Kurosaki, T.; Kawanabe, S.; Kodama, Y.; Fumoto, S.; Nishida, K.; Nakagawa, H.; Higuchi, N.; Nakamura, T.; Kitahara, T.; Sasaki, H. Hepatic Gene Delivery System Electrostatically Assembled with Glycyrrhizin. Mol. Pharm. 2014, 11, 1369-1377. [CrossRef] [PubMed]

67. Su, X.; Wu, L.; Hu, M.; Dong, W.; Xu, M.; Zhang, P. Glycyrrhizic Acid: A Promising Carrier Material for Anticancer Therapy. Biomed. Pharmacother. 2017, 95, 670-678. [CrossRef] [PubMed]

68. Matsuoka, K.; Miyajima, R.; Ishida, Y.; Karasawa, S.; Yoshimura, T. Aggregate Formation of Glycyrrhizic Acid. Colloids Surf. A Physicochem. Eng. Asp. 2016, 500, 112-117. [CrossRef]

69. Borisenko, S.N.; Lekar', A.V.; Vetrova, E.V.; Filonova, O.V.; Borisenko, N.I. A Mass Spectrometry Study of the Self-Association of Glycyrrhetinic Acid Molecules. Russ. J. Bioorganic Chem. 2016, 42, 716-720. [CrossRef]

70. Zhang, C.; Liu, Z.; Zheng, Y.; Geng, Y.; Han, C.; Shi, Y.; Sun, H.; Zhang, C.; Chen, Y.; Zhang, L.; et al. Glycyrrhetinic Acid Functionalized Graphene Oxide for Mitochondria Targeting and Cancer Treatment In Vivo. Small 2018, 14, 1-16. [CrossRef]

71. Wang, W.; Luo, M.; Fu, Y.; Wang, S.; Efferth, T.; Zu, Y. Glycyrrhizic Acid Nanoparticles Inhibit LPS-Induced Inflammatory Mediators in 264.7 Mouse Macrophages Compared with Unprocessed Glycyrrhizic Acid. Int. J. Nanomed. 2013, 8, 1377-1383. [CrossRef]

72. Zu, Y.; Meng, L.; Zhao, X.; Ge, Y.; Yu, X.; Zhang, Y.; Deng, Y. Preparation of 10-Hydroxycamptothecin-Loaded Glycyrrhizic Acid-Conjugated Bovine Serum Albumin Nanoparticles for Hepatocellular Carcinoma-Targeted Drug Delivery. Int. J. Nanomed. 2013, 8, 1207-1222. [CrossRef] 
73. Yang, F.H.; Zhang, Q.; Liang, Q.Y.; Wang, S.Q.; Zhao, B.X.; Wang, Y.T.; Cai, Y.; Li, G.F. Bioavailability Enhancement of Paclitaxel via a Novel Oral Drug Delivery System: Paclitaxel-Loaded Glycyrrhizic Acid Micelles. Molecules 2015, 20, 4337-4356. [CrossRef] [PubMed]

74. Zeeshan, M.; Ali, H.; Khan, S.; Mukhtar, M.; Khan, M.I.; Arshad, M. Glycyrrhizic Acid-Loaded PH-Sensitive Poly-(Lactic-CoGlycolic Acid) Nanoparticles for the Amelioration of Inflammatory Bowel Disease. Nanomedicine 2019, 14, 1945-1969. [CrossRef] [PubMed]

75. Bernela, M.; Ahuja, M.; Thakur, R. Enhancement of Anti-Inflammatory Activity of Glycyrrhizic Acid by Encapsulation in Chitosan-Katira Gum Nanoparticles. Eur. J. Pharm. Biopharm. 2016, 105, 141-147. [CrossRef]

76. Tong, T.; Hu, H.; Zhou, J.; Deng, S.; Zhang, X.; Tang, W.; Fang, L.; Xiao, S.; Liang, J. Glycyrrhizic-Acid-Based Carbon Dots with High Antiviral Activity by Multisite Inhibition Mechanisms. Small 2020, 16, 1-12. [CrossRef]

77. Wang, Y.; Zhao, B.; Wang, S.; Liang, Q.; Cai, Y.; Yang, F.; Li, G. Formulation and Evaluation of Novel Glycyrrhizic Acid Micelles for Transdermal Delivery of Podophyllotoxin. Drug Deliv. 2016, 23, 1623-1635. [CrossRef] [PubMed]

78. Cho, T.; Han, H.S.; Jeong, J.; Park, E.M.; Shim, K.S. A Novel Computational Approach for the Discovery of Drug Delivery System Candidates for COVID-19. Int. J. Mol. Sci. 2021, 22, 2815. [CrossRef] 